\title{
Psychological Assessment in Children With Epilepsy and Their Mothers
}

\author{
Epilepsili Çocuklarda ve Annelerinde Psikolojik Değerlendirme
}

\author{
Berna BAL, Murat ELEVLI, Nilgun SELCUK DURU
}

University of Health Sciences, Haseki Training and Research Hospital, Department of Pediatrics, Istanbul, Turkey

\begin{abstract}
Objective: Epilepsy is a chronic disease with high morbidity. Our study aims to investigate the scores of anxiety and depression in children with epilepsy and their mothers and the role of parental attitudes in these children.

Material and Methods: The study included 35 children with epilepsy and their mothers. Control group consisted of 35 healthy children of similar age and sex to the study group and their mothers. Parenting Style Inventory (PSI), Parental Attitude Research Instrument (PARI), Beck Depression Inventory (BDI) and Beck Anxiety Inventory (BAI), Revised Children's Anxiety and Depression Scale - Parent version (RCADS-P) scales were used in the patient and control groups.

Results: There was no statistically significant difference between mother anxiety and depression scores in terms of $\mathrm{BDI}$ and BAI scales. There were no significant differences between the total and subscale scores of the anxiety and depression in the children of study and control groups in terms of RCADS-P. Strictness/supervision subscale of PSI average was statistically significantly higher in the patient group but the Psychological Autonomy subscale average was found lower. The mean scores of Excessive Maternity and Obsession and Discipline subscale of PARI were significantly higher in the patient group.
\end{abstract}

Conclusion: Mothers of children with epilepsy may be overprotective or authoritarian. Overprotective or authoritative parental attitudes in children can lead to loss of self-esteem. Therefore, besides the treatment of children with epilepsy, attention should be paid to improving the wrong attitudes of their parents.

Key Words: Anxiety, Child, Depression, Epilepsy, Parental attitudes

\section{ÖZ}

Amaç: Epilepsi morbiditesi yüksek, kronik bir hastalıktır. Çalışmamız; epilepsili çocuklarda ve annelerinde anksiyete ve depresyon skorlarını ve bu çocuklarda ebeveyn tutumlarının rolünü araşıırmayı amaçlamaktadır.

Gereç ve Yöntemler: Çalışmaya 35 epilepsili çocuk ve anneleri dahil edildi. Kontrol grubu, çalışma grubuna benzer yaş ve cinsiyetteki 35 sağıklı çocuk ve annelerinden oluşturuldu. Hasta ve kontrol gruplarında çocuk yetistirme stilleri envanteri, aile hayatı ve çocuk yetiştirme tutum ölçeği (PARI), Beck depresyon envanteri (BDE), Beck anksiyete envanteri (BAE), Revize edilmiş çocuk anksiyete ve depresyon ölçeği-Ebeveyn versiyonu (RCADS-P) ölçekleri kullanılımıştır.

Bulgular: Anne anksiyete ve depresyon skorları arasında istatistiksel olarak anlamlı bir fark yoktu. Çalışma ve kontrol grubu çocuklarının anksiyete ve depresyon toplam ve alt ölçek puanları arasında RCADS-P açısından anlamlı bir fark bulunmamıştır. Hasta grubunda çocuk yetiştirme stilleri envanterinin kontrol/denetleme alt ölçeği istatistiksel olarak

BAL B

BAL B
ELEVLIM

SELCUK DURU N
Conflict of Interest / Çıkar Çatışması: On behalf of all authors, the corresponding author states that there is no conflict of interest.

: 0000-0003-2871-9378 Ethics Committee Approval / Etik Kurul Onayr: The study was approved by the Health Sciences University, Istanbul Training and Research Hospital : 0000-0002-0510-965X Clinical Research Ethics Committee, dated 10.07.2018 and numbered 1347.

: 0000-0001-9105-0529

Contribution of the Authors / Yazarların katkıs: BAL B: Constructing the hypothesis or idea of research and/or article, Planning methodology to reach the Conclusions, Organizing, supervising the course of progress and taking the responsibility of the research/study, Taking responsibility in patient follow-up, collection of relevant biological materials, data management and reporting, execution of the experiments, Taking responsibility in logical interpretation and conclusion of the results, Taking responsibility in necessary literature review for the study. ELEVLI M: Constructing the hypothesis or idea of research and/or article, Planning methodology to reach the Conclusions, Organizing, supervising the course of progress and taking the responsibility of the reserch/study, Taking responsibility in patient follow-up, collection of relevant biological materials, data management and repoting, (a) for the study. SELCUK DURU N: Taking responsibility in logical interpretation and conclusion of the results, Taking responsibility in the writing of the whole or important parts of the study, Reviewing the article before submission scientifically besides spelling and grammar.

How to cite / Atıf yazım şekli : Bal B, Elevli M and Selcuk Duru N. Psychological Assessment in Children With Epilepsy and Their Mothers . Turkish J Pediatr Dis 2021;15:494-500. 
anlamlı derecede yüksek iken, psikolojik özerklik alt ölçeği ortalamasının daha düşük olduğu görülmüştür. PARl'nin aşııı koruyucu annelik ve baskı/disiplin alt ölçeği puan ortalamaları hasta grubunda anlamlı olarak daha yüksekti.

Sonuç: Epilepsili çocukların anneleri aşıı korumacı veya otoriter olabilir. Çocuklarda aşırı korumacı veya otoriter ebeveyn tutumları, öz güven kaybına neden olabilir. Bu nedenle epilepsili çocukların tedavisinin yanısıra ebeveynlerinin yanlıș tutumlarının düzeltilmesine de önem verilmelidir.

Anahtar Sözcükler: Anksiyete, Çocuk, Depresyon, Epilepsi, Ebeveyn tutumları

\section{INTRODUCTION}

Epilepsy is the most common chronic neurological disease of childhood and adolescence, characterized by recurrent seizures caused by abnormal discharge of neuronal cells from congenital or acquired disorders (1).

The effect of epilepsy in children is not limited to the disease itself; it also negatively affects behavioral and cognitive functions and quality of life in children. The unpredictable process related to the seizures creates important psychological problems for the child as well as for the family (2-4). It is thought that a significant number of children with epilepsy will experience anxiety or depression. In studies, the prevalence of anxiety in children with epilepsy is about 30-35\%, while the prevalence of depression is $12.7-36.5 \%$ (3). Chronic illness itself is a risk factor for anxiety and depression. In addition, antiepileptic drugs may contribute to neurobehavioral and psychiatric outcomes (2).

In a study, it was determined that the parents of children with epilepsy had higher levels of anxiety compared to the control group and the mothers experienced difficulties due to higher responsibilities of care than fathers. It was stated in this study that positive changes could be observed in this condition after an appropriate intervention (4).

Our study aims to investigate the scores of anxiety and depression in children with epilepsy and their mothers and the role of parental attitudes in these children.

\section{METARIAL and METHODS}

A cross-sectional study was conducted in the department of pediatrics at our hospital. The study included a group of children with epilepsy and their mothers, as well as a control group of healthy children and mothers of similar age and sex. Patients with a chronic disease other than epilepsy or a diagnosis of psychiatric disease were excluded from the study. The mothers with anxiety-causing conditions such as newborn babies, marital discord, and chronic disease were excluded from the study. The study was approved by the Health Sciences University, Istanbul Training and Research Hospital, Clinical Research Ethics Committee, dated 10.07.2018 and numbered 1347. Informed consent was obtained from the mothers of the patients and the controls.

Socio-demographic information (age, gender, family type, economic status, mother's occupation and education level) was collected using a structured questionnaire.
Duration of epilepsy and usage drug, type and frequency of seizures were recorded from medical records of patients.

Parental Style Inventory (PSI) was administered to all children. The Beck depression inventory (BDI), Beck anxiety inventory (BAI), parental attitude research instrument (PARI) and revised children's anxiety and depression scale - parent (RCADS-P) were filled by mothers.

Parenting Style Inventory (PSI) is designed to evaluate the characteristics of the parenting style (5). Yılmaz conducted Turkish translation and adaptation of the PSI. It has a total of 26 items (acceptance/participation, 9 items; stiffness/control, 8 items; and psychological autonomy, 9 items) (6). Cronbach's a have been reported to be $0.72,0.82$ and 0.86 respectively for these sub-scales.

$\mathrm{BDI}$ was created to measure the severity of depression and identify the disease. The Turkish translation and adaptation of the BDI were conducted by Hisli (7). Cronbach's a have been reported to be 0.80 (7). Depression-specific symptoms and behaviors are defined in a series of sentences and are a 21item scale. Each item gets points between 0-3 and higher total scores indicate more severe depressive symptoms. In Turkey, 15 and higher scores generally accepted as depression (7).

$\mathrm{BAI}$ is a scale consisting of 21 items developed to determine the level of anxiety of adult and adolescent individuals. The validity and reliability study of the scale in Turkish was conducted by Ulusoy (8). Each item gets points between $0-3$. The limit value of the scale is 17 .

PARI is a scale consisting of 60 items. The scale that was developed by Schaefer (9) in 1958 was adapted to Turkish in a shortened form by LeCompte and friends in 1978 (10). Cronbach's a was found as 0.64. The scale used to evaluate the parenting attitudes of the parents. It is filled by parents and contains five sub-scales: excessive maternity, democratic attitude and equality, rejection of housewife, family incompability, and pressure and disciplines. The items in the scale are within a four-step evaluation system, the subjects' opinions I find very appropriate "(4 points)," I find it quite appropriate "(3 points)," I find it appropriate "(2 points)," I do not find it appropriate " (1 score) options.

In the RCADS-P, parents are asked to fill in the items (never $=0$, sometimes $=1$, often $=2$, always $=3$ ) that include the frequency of symptoms and behaviors related to anxiety and depression in their child. The Turkish translation and adaptation 
of the RCADS-P were conducted by Gormez et al. (11). The threshold T score was determined as 65 and above.

\section{Statistical analysis}

Analyses were performed using the SPSS version 15.0 package program for Windows. Results are expressed as mean SD or median (lower and upper limit) for descriptive data. The normality of the parameters was tested using the Shapiro-Wilk normality test. Parametric (Student's t-test) and nonparametric tests (Mann-Whitney $U$ test) were used for between-group comparisons. A Chi-square test was used for the comparison of qualitative data. Values of $p<0.05$ were considered statistically significant.

\section{RESULTS}

A total of 70 children, adolescents, and their mothers, including 35 cases with epilepsy and 35 controls between the ages of $8-18$, were included in the study. The median age of the patient group was $11.7 \pm 3.2$; the control group was $11.8 \pm 2.7$. The patient group consisted of $54.3 \%$ girls and $45.7 \%$ boys; $57.1 \%$ of the control group are girls and $42.9 \%$ are boys. There was no statistically significant difference between the two groups in terms of age and gender, family type, economic status, schooling, number of siblings and sequence of child ( $p>0.05$ ). There was no statistically significant difference between the two groups in terms of the mother's education level and the profession (Table I).

Table I: Characteristics of mothers and children of the study groups

\begin{tabular}{|c|c|c|c|}
\hline & Epileptic group $(n=30)$ & Controls $(n=30)$ & p \\
\hline $\begin{array}{l}\text { Children } \\
\text { Age (year) mean } \pm S D\end{array}$ & $11.7 \pm 3.2$ & $11.8 \pm 2.7$ & 0.714 \\
\hline $\begin{array}{l}\text { Gender } \mathbf{n}(\%) \\
\text { Female } \\
\text { Male }\end{array}$ & $\begin{array}{l}19(54.3) \\
16(45.7)\end{array}$ & $\begin{array}{l}20(57.3) \\
15(42.9)\end{array}$ & 0.810 \\
\hline Number of siblings mean \pm SD & $2.77 \pm 0.98(1-7)$ & $2.34 \pm 0.87(1-4)$ & 0.115 \\
\hline $\begin{array}{l}\text { Schooling } \\
\text { No } \\
\text { 1-4.class } \\
\text { 5-8. class } \\
\text { 9-12. class }\end{array}$ & $\begin{aligned} 1 & (2.9) \\
15 & (42.9) \\
11 & (31.4) \\
8 & (22.9)\end{aligned}$ & $\begin{aligned} 0 & (0.0) \\
15 & (42.9) \\
14 & (40.0) \\
6 & (17.1)\end{aligned}$ & 0.738 \\
\hline $\begin{array}{l}\text { Family type } \mathbf{n}(\%) \\
\text { Nuclear } \\
\text { Joint }\end{array}$ & $\begin{array}{c}32(91.4) \\
3(8.6)\end{array}$ & $\begin{array}{r}28(80.0) \\
7(20.0)\end{array}$ & 0.172 \\
\hline $\begin{array}{l}\text { Economic status } \\
\text { Lower } \\
\text { Middle } \\
\text { Upper }\end{array}$ & $\begin{array}{l}27(77.1) \\
5(14.3) \\
3(8.6)\end{array}$ & $\begin{array}{l}24(68.6) \\
9(25.7) \\
2(5.7)\end{array}$ & 0.334 \\
\hline Sequence of child & $1.97 \pm 0.98(1-4)$ & $1.69 \pm 0.90(1-4)$ & 0.190 \\
\hline $\begin{array}{l}\text { Duration of epilepsy mean } \pm \text { SD } \\
\text { Month }\end{array}$ & $52.2 \pm 35.8$ & & \\
\hline $\begin{array}{l}\text { Duration of usage drog mean } \pm S D \\
\text { Month }\end{array}$ & $40.5 \pm 28.5$ & & \\
\hline $\begin{array}{l}\text { Type of seizure } \mathbf{n}(\%) \\
\text { Generalize } \\
\text { Focal } \\
\text { Absens }\end{array}$ & $\begin{array}{r}23(65.7) \\
8(22.9) \\
4(11.4)\end{array}$ & & \\
\hline $\begin{array}{l}\text { Frequency of seizures Per year } \\
<5 \\
5-10 \\
>10\end{array}$ & $\begin{array}{l}23(65.7) \\
9(25.7) \\
3(8.6)\end{array}$ & & \\
\hline $\begin{array}{l}\text { Mother } \\
\text { Education n (\%) } \\
\text { No } \\
\text { Elementary } \\
\text { Middle } \\
\text { High }\end{array}$ & $\begin{aligned} 1 & (2.9) \\
25 & (71.4) \\
5 & (14.3) \\
1 & (2.9)\end{aligned}$ & $\begin{aligned} 1 & (2.9) \\
22 & (62.9) \\
8 & (22.9) \\
1 & (2.9)\end{aligned}$ & 0.868 \\
\hline $\begin{array}{l}\text { Occupation n (\%) } \\
\text { Homemaker } \\
\text { Employed }\end{array}$ & $\begin{array}{c}33(94.3) \\
2(5.7)\end{array}$ & $\begin{array}{r}28(80.0) \\
7(20.0)\end{array}$ & 0.151 \\
\hline
\end{tabular}


Table II: Comparison of sub-scale scores of parenting style inventery (PSI) and Revised Children's Anxiety and Depression Scale Parent version (RCADS-P) in the patient and control groups.

\begin{tabular}{|c|c|c|c|c|c|}
\hline \multirow{2}{*}{ PSI } & \multicolumn{2}{|c|}{ Patient Group } & \multicolumn{2}{|c|}{ Control Group } & \multirow{2}{*}{$\mathbf{p}$} \\
\hline & Mean \pm SD & Min-Max & Mean \pm SD & Min-Max & \\
\hline Acceptance/participation & $31.7 \pm 2.9$ & $25-35$ & $31.4 \pm 3.1$ & $21-38$ & 0.507 \\
\hline Stiffness/Control & $23.7 \pm 3.3$ & $16-29$ & $21.7 \pm 4.3$ & $13-33$ & 0.010 \\
\hline Psychological autonomy & $6.9 \pm 1.8$ & $6-14$ & $8.0 \pm 2.2$ & $6-14$ & 0.014 \\
\hline RCADS-P & \multicolumn{2}{|c|}{$\mathrm{n}(\%)$} & \multicolumn{2}{|c|}{ n (\%) } & $p$ \\
\hline Separation Anxiety & \multicolumn{2}{|c|}{$5(14.3)$} & \multicolumn{2}{|c|}{$5(14.3)$} & 1.000 \\
\hline General Anxiety & \multicolumn{2}{|c|}{$1(2.9)$} & \multicolumn{2}{|c|}{$0(0.0)$} & 1.000 \\
\hline Panic & \multicolumn{2}{|c|}{$3(8.6)$} & \multicolumn{2}{|c|}{$0(0.0)$} & 0.239 \\
\hline Social Phobia & \multicolumn{2}{|c|}{$3(8.6)$} & \multicolumn{2}{|c|}{$1(2.9)$} & 0.614 \\
\hline Obsessions / compulsions & \multicolumn{2}{|c|}{$2(5.7)$} & \multicolumn{2}{|c|}{$0(0.0)$} & 0.493 \\
\hline Depression & \multicolumn{2}{|c|}{$3(8.6)$} & \multicolumn{2}{|c|}{$0(0.0)$} & 0.239 \\
\hline Total Anxiety & \multicolumn{2}{|c|}{$2(5.7)$} & \multicolumn{2}{|c|}{$0(0.0)$} & 0.493 \\
\hline Total Anxiety/ Depression & \multicolumn{2}{|c|}{$3(8.6)$} & \multicolumn{2}{|c|}{$0(0.0)$} & 0.239 \\
\hline
\end{tabular}

PSI: Parenting Style Inventory, RCADS-P: Revised Children's Anxiety and Depression Scale - Parent

Table III: Comparison of BDI, BAI and PARI subgroup scores of mothers in study and control groups.

\begin{tabular}{|c|c|c|c|c|c|}
\hline & \multirow{2}{*}{\multicolumn{2}{|c|}{$\begin{array}{c}\text { Patient Group } \\
\mathbf{n}(\%)\end{array}$}} & \multirow{2}{*}{\multicolumn{2}{|c|}{$\begin{array}{c}\text { Control Group } \\
\text { n (\%) }\end{array}$}} & \multirow{2}{*}{$\mathbf{p}$} \\
\hline & & & & & \\
\hline BDI & \multicolumn{2}{|c|}{$3(8.6)$} & \multicolumn{2}{|c|}{$6(17.1)$} & 0.477 \\
\hline BAl & \multicolumn{2}{|c|}{$14(40.0)$} & \multicolumn{2}{|c|}{$8(22.9)$} & 0.197 \\
\hline PARI subgroups & Mean \pm SD & Min-Max & Mean \pm SD & Min-Max & $\mathbf{p}$ \\
\hline Excessive Maternity & $53.3 \pm 6.4$ & $39-64$ & $45.8 \pm 8.6$ & $26-64$ & $<0.001$ \\
\hline Democratic Attitude and Equality & $30.9 \pm 3.0$ & $24-36$ & $30.5 \pm 3.5$ & $22-36$ & 0.763 \\
\hline Rejection of Housewife & $28.1 \pm 8.2$ & $16-48$ & $28.2 \pm 7.2$ & $18-49$ & 0.860 \\
\hline Family Incompability & $15.2 \pm 4.8$ & $6-24$ & $14.1 \pm 4.2$ & $6-24$ & 0.220 \\
\hline Pressure and Disciplines & $45.3 \pm 7.8$ & $34-58$ & $39.6 \pm 6.9$ & $29-63$ & 0.004 \\
\hline
\end{tabular}

BDI: Beck Depression Inventory, BAI: Beck Anxiety Inventory, PARI: Parental Attitude Research Instrument

Based on the time since the diagnosis of children with epilepsy, the duration of the disease was found to be $52.2 \pm 35.8$ months, with a minimum of 9 and a maximum of 174 months. Seven patients (20\%) had only one epileptic seizure at the time of diagnosis, and their seizures were followed up under control with antiepileptic treatment. Considering epileptic seizure type, $65.7 \%$ of the patients were generalized, $22.9 \%$ were focal and $11.4 \%$ were absence (Table I).

When evaluated in terms of the time of last seizure, $45.7 \%$ of patients stated that they had experienced their last attack in the last few years, $20 \%$ in the last six months, $2.9 \%$ in the last month, and $11.4 \%$ in the last week. There was a history of status epilepticus in $17.1 \%$ of the patients.

When PSI was analyzed, the mean score of the stiffness/control dimension in the patient group was statistically significantly higher than the control group, and the mean score of the psychological autonomy dimension was statistically significantly lower than the control group ( $p=0.010$ and $p=0.014)$. There was no statistically significant difference between the two groups in the mean score of the acceptance/participation dimension ( $p$ $=0.507$ ) (Table II). Although there is no statistically significant difference in the anxiety, separation anxiety, panic, social phobia, obsession/compulsion, depression, total anxiety, total anxiety depression rates in the patient and control groups in children, the mean scores are higher in the patient group (Table II).

Although there was no statistically significant difference in the $\mathrm{BDI}$ and $\mathrm{BAI}$ ratios of the mothers of the patient and control groups, the mean scores of BAI score was higher in the patient group ( $p=0.477$ and $p=0.197$, respectively) (Table III). There was no statistically significant difference in the Democratic Attitude and Equality, Rejection of Housewife, Family Incompatibility of mothers in PARI. In the patient group, Excessive Maternity and Pressure and Discipline scores of the mothers were statistically significantly higher than the control group $(p<0.001 p=0.004)$ (Table III). 
Table IV: Corelation of PARI subscale scores with sociodemographic data in the study group.

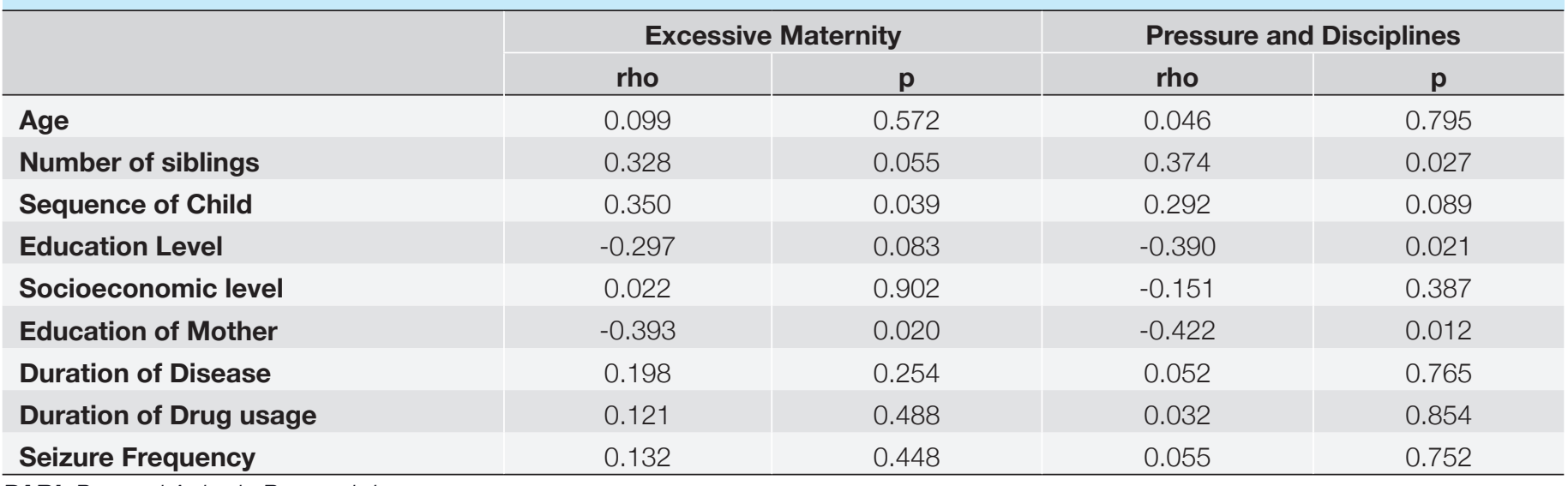

PARI: Parental Attitude Research Instrument

When the children of the mothers with and without depression according to the BDI in the patient group were compared, there was no statistically significant correlation between the scores of RCADS-P and PSI ( $p>0.05)$. When the children of the mothers with and without anxiety according to the BAI were compared in the patient group, no statistically significant correlation was found between the scores of RCADS-P and PSI (p>0.05).

In the patient group, the Pressure and Discipline dimension of the mothers was found to be statistically significantly correlated with the stiffness/control dimension of the children ( $p=0.045)(r=0.341)$. In the patient group, a statistically significant correlation was found between the stiffness/control, Psychological Autonomy dimensions and age of the children ( $p$ $=0.013 r=0.415, p=0.001 r=0.522$, respectively).

In the patient group, the Extreme Maternity subscale of mothers was found to be positively correlated with the number of children in the family, negatively with the educational status of the mother, and the Pressure and Discipline subscale was statistically significantly related to the educational level of the mother $(p=0.039 r=0.350, p=0.020 r=-0.393, p=0.021 r=$ $-0.39, p=0.012 r=-0.422$, respectively) (Table IV).

\section{DISCUSSION}

In our study, the depression and anxiety scores of children with epilepsy and their mothers were not significantly different from healthy children and their mothers. Excessive Maternity and Pressure and Discipline scores in the mothers of epileptic children were statistically significantly higher than the control group mothers. In addition to, the mean score of the stiffness/ control dimension in the patient group was statistically significantly higher than the control group, and the mean score of the psychological autonomy dimension was statistically significantly lower than the control group.

There are many publications in the literature showing that a child with epilepsy is a source of stress for the family (12-16).
The seizures usually frighten the parents and worry about the death of their children (17). In a review by Ferro, the prevalence of depression in mothers of children with epilepsy was reported to be $12-49 \%$ (18-23). A study conducted by Akay in Turkey showed that mothers of children with epilepsy were significantly higher depression scores compared to the control group (24). In contrast to these studies, Baki et al. (25) did not show a significant difference in terms of depression between mothers with or without children with epilepsy. In our study, there was no statistically significant difference between the mothers of children with epilepsy and the control group in terms of anxiety and depression scores. These results may be due to the low number of patients compared to the studies in the literature, or the fact that children with epilepsy in our case group were well controlled and the number of seizures was lower than in other studies.

Clinical and population-based studies have shown that children and adolescents with epilepsy have a higher rate of anxiety and depression than healthy children (26-31). In an epidemiological study conducted in the United Kingdom, Davies et al. (26) found emotional problems as $16.7 \%$ in complicated epilepsy, $16 \%$ in uncomplicated epilepsy and $4.2 \%$ in healthy group as a comparison group. In our study, no statistically significant difference was found between the anxiety and depression scores of children with epilepsy and the control group. This may be due to the low frequency of seizures in the epileptic group. In a study by Berg et al. (32), it was reported that anxiety and depression were more common in children with continuing seizures than well-controlled epilepsy.

Dunn et al. (22) showed that family history is an important clue for depression in a child with epilepsy, but Baki et al. (25) did not observe a relationship between depression scores of children with epilepsy and their mothers. In our study, this relationship could not be evaluated since there was no significant difference between anxiety and depression scores in children with and without epilepsy and their mothers. 
In the study of Akay (24), the Democratic Attitude scores of the parents of the children with epilepsy were significantly lower than the control group, while the scores of Excessive Pressure, Unbalanced-Unstable Attitude ratios were found to be higher. In this study, PARI's Extreme Maternity sub-group scores were found to be significantly higher in mothers of children who had more than one seizure per month (24). Additionally, prolongation of the disease was associated with higher rates of Overprinting - Authoritarian parental attitudes (24).

In our study, similar to the study of Akay, the scores of Extreme Maternity and Pressure and Discipline of mothers with children with epilepsy were found to be significantly higher (24). These results show that parents are not successful in developing a supportive and sharing relationship. In the study group, the Pressure and Discipline dimension in PARI was found to be positively associated with the Stiffness/Control subscale in PSI. From this point of view, it is possible to say that mothers have an oppressive and interventionist attitude towards their children with epilepsy, instead of democratic competence.

Thornton (27) revealed that families of children with epilepsy experience problems in the roles of individuals and in fulfilling their roles in the family. According to the study, the reason for this is that the parent thinks that the child who is diagnosed with epilepsy needs closer supervision or activity restriction and that responsibility is not shared equally among family members (27). The family may show attitudes such as excessive oppression, excessive protection, or opposite attitudes rejection, unmeasured punishment. Overprotective or authoritarian parental attitudes that families exhibit with the instinct to protect and watch for more because of epilepsy can lead to loss of self-confidence in children, as well as in our study, leading to a decrease in their psychological autonomy (27).

Considering the relationship between socio-demographic characteristics and parental attitudes in PARI, the scores of Extreme Maternity were found to be positively correlated with the sequence of child and negatively correlated with the education level of the mother. The Pressure and Discipline dimension was negatively related to the education level of the child and mother. In an epidemiological study conducted in parents of healthy children with PARI, Extreme Maternity and Pressure and Discipline dimension scores were negatively correlated with the educational status of the mothers as in our study; however, these subscale scores were found to be significantly higher in unemployed mothers (33). In the same study, it was found that the scores of Rejecting Housewife and Family Incompatibility subscales were significantly high in the mothers with low monthly income (33). In our study, no significant relationship was found between the occupation of the mothers and the scale scores. This may be due to the low number of working mothers in our study.

There are some limitations of our study. First, it is the small sample size. Psychiatric symptoms are difficult to diagnose in mentally retarded children and adolescents (2). Not including children with neurocognitive deficiencies, whose psychological evaluation is difficult, made the study group smaller. Second, most of the children with epilepsy in our study were mild cases.

In conclusion, the study shows that epilepsy has a negative effect on Repressive- Authoritarian and Overprotective parental attitudes. Behavior and personality disorders may occur in children due to the parents' incompetent attitudes. The psychosocial aspect of epilepsy should be kept in mind of the pediatricians, and it should always be taken into consideration that patients and their families may need support in this regard.

\section{REFERENCES}

1. Iliescu C, Craiu D. Diagnostic Approach of Epilepsy in Childhood and Adolescence. Maedica (Bucur) 2013; 8: 195-9.

2. Plevin D, Smith N. Assessment and Management of Depression and Anxiety in children and adolescents with epilepsy. Behav Neurol 2019; 2019:2571368.

3. Reilly C, Agnew R, Neville BGR. Depression and anxiety in childhood epilepsy: a review. Seizure 2011;20:589-97.

4. Ramaglia G, Romeo A, Viri M, Lodi M, Sacchi S, Cioffi G. Impact of idiopathic epilepsy on mothers and fathers: Strain, burden of care, worries and perception of vulnerability. Epilepsia 2007;48: 1810-3.

5. Lamborn SD, Mounts NS, Steinberg L, Darnbush SM. Patterns of competence and adjustment among adolescents from authoritative, authoritarian, indulgent, and neglectful families. Child Dev 1991;62:1049-65.

6. Yılmaz A. Anne-Baba Tutum Ölçeği'nin güvenirlik ve geçerlilik çalışması. Çocuk ve Gençlik Ruh Sağlığı Derg 2000;7:160-73.

7. Hisli N. Beck Depresyon Envanterinin geçerliliği üzerine bir çalışma. Türk Psikol Derg 1998;6:118-26.

8. Ulusoy M, Şahin N, Erkmen H. Turkish version of Beck Anxiety inventory: Psychometric Properties. J Cogn Psychother 1998;12:163-72.

9. Schaffer E, Bell R. Development of a parental attitude research instrument (PARI). Child Dev 1958;29:339-61.

10. LeCompte G, LeCompte A, Özer S. Üç sosyoekonomik düzeyde Ankaralı annelerin çocuk yetiştirme tutumları: Bir ölçek uyarlaması. Psikoloji Dergisi 1978;1:5-8.

11. Gormez V, Kilincaslan A, Ebesutani C, Orengul AC, Kaya I, Ceri V, et al. Psychometric Properties of the parent Version of the Revised Child Anxiety and Depression Scale in a Clinical Sample of Turkish Children and Adolescents. Child Psychiatry Hum Dev 2017; 48: 922-33.

12. Ekinci O, Isik U, Gunes S, Yildirim C, Killi Y, Guler G. Self-concept in children and adolescents with epilepsy: The role of family functioning, mothers' emotional symptoms and ADHD Brain Dev 2016; 38: 714-22.

13. Singer GH. Meta-analysis of comparative studies of depression in mothers of children with and without developmental disabilities. Am J Ment Retard 2006; 111: 155-69.

14. O'Toole S, Gallagher P, Ailbhe Benson A, Shahwan A, Austin $\mathrm{JK}$, Lambert V. Exploring the relationship between parent-child communication about epilepsy and psychosocial well-being. J Health Psychol 2019;1359105319871642.

15. Khajeh A, Firouzkoohi M, Miri-Aliabad G, Fayyazi A, Miri Bonjar M. Prevalence of Anxiety, Stress and Depressive Symptoms Among Mothers of Children With Epilepsy. Health Scope 2015;4:e18688. 
16. Carlson JM, Miller PA. Family burden, child disability, and the adjustment of mothers caring for children with epilepsy: Role of social support and coping. Epilepsy Behav 2017; 68:168-73.

17. Besag F, Nomayo A, Pool F. The reactions of parents who think that a child is dying in a seizure : in their own words. Epilepsy Behav 2005; 7: 517-23.

18. Ferro MA, Speechley KN. Depressive symptoms among mothers of children with epilepsy: a review of prevalence, associated factors, and impact on children. Epilepsia 2009; 5: 2344-54.

19. Chiou HH, Hesieh LP. Parenting stress in parents of children with epilepsy and asthma. J Child Neurol 2008;23: 301-6.

20. Shore CP, Austin JK, Huster GA, Dunn DW. Identifying risk factors for maternal depression in families of adolescents with epilepsy. JSPN 2002; 7: 71-80.

21. Rodenburg R, Marie Meijer A, Deković M, Aldenkamp AP. Family predictors of psychopathology in children with epilepsy. Epilepsia 2006;47:601-14.

22. Dunn DW, Austin JK, Huster GA. Symptoms of depression in adolescents with epilepsy. J Am Acad Child Adolesc Psychiatry 1999;38: 1132-8.

23. Wood LJ, Sherman EM, Hamiwka LD, Blackman MA, Wirrell EC. Maternal depression: the cost of caring for a child with intractable epilepsy. Pediatr Neurol 2008;39: 418-22.

24. Akay AP, Hiz Kurul S, Ozek H, Cengizhan S, Emiroglu N, Ellidokuz $H$. Maternal reactions to a child with epilepsy: Depression, anxiety, parental attitudes and family functions. Epilepsy Research 2011; 3: 213-20.
25. Baki O, Erdogan A, Kantarci O, Akisik G, Kayaalp L, Yalcinkaya C. Anxiety and depression in children with epilepsy and their mothers. Epilepsy Behav 2004;5: 958-64.

26. Davies S, Heyman I, Goodman R. A population survey of mental health problems in children with epilepsy. Dev Med Child Neurol 2003;45: 292-5.

27. Thornton N, Hamiwka L, Sherman E, Tse E, Blackman M, Wirrell E. Family function in cognitively normal children with epilepsy: Impact on competence and problem behaviors. Epilepsy Behav 2008;12: 90-5.

28. LaGrant B, Marquis BO, Berg AT, Grinspan ZM. Depression and anxiety in children with epilepsy and other chronic health conditions: National estimates of prevalence and risk factors. Epilepsy Behav 2020;103:106828.

29. Roeder R, Roeder K, Asano E, Chugani HT. Depression and mental health help-seeking behaviors in a predominantly African American population of children and adolescents with epilepsy. Epilepsia 2009;50: 1943-52.

30. Dunn DW, Austin JK, Perkins SM. Prevalence of psychopathology in childhood epilepsy: categorical and dimensional measures. Dev Med Child Neurol 2009; 51: 364-72.

31. Jones JE, Watson R, Sheth R. Psychiatric comorbidity in children with new onset epilepsy. Dev Med Child Neurol 2007; 49: 493-7.

32. Berg AT, Caplan R, Hesdorffer DC. Psychiatric and neurodevelopmental disorders in childhood-onset epilepsy. Epilepsy Behav 2011; 20: 550-5.

33. Şanlı D, Öztürk C. Annelerin Çocuk Yetiştirme Tutumlarını Etkileyen Etmenlerin İncelenmesi. Dokuz Eylül Üniversitesi Buca Eğitim Fakültesi Dergisi 2012; 32: 31-48. 